\title{
Pemahaman Produk Bank Syariah Guru Pondok Pesantren Di Kabupaten Tangerang dan Sikap Menggunakan Produk Bank Syariah
}

\author{
Oleh: \\ Maskur Rosyid \\ Aris
}

Sekolah Tinggi Ekonomi Syariah (STES) Islamic Village Tangerang Jl. Islamic Raya Kelapa Dua Tangerang-Banten

\begin{abstract}
Abstrak: Keberadaan pondok pesantren di Kabupaten Tangerang berpengaruh terhadap pola pikir masyarakat dan di kelola oleh orang yang mengerti keagamaan. Seyogyanya, mereka mengerti konsep perbankan Syariah. Pemahaman yang mereka miliki dapat menalari pada anak didiknya, dapat menjadi harapan berkembangnya bank syariah. Tulisan ini ingin melihat tingkat pemahaman guru pondok pesantren terhadap produk bank syariah, dan apakah berpengaruh terhadap sikap menggunakan produk tersebut di Kabupaten Tangerang, dengan menggunakan metode Deskriptif Kualitatif. Tempat penelitian di Pondok Pesantren Al-Ma'mur, Islahul Ummah dan Daar el-Qolam. Dari hasil analisis pemahaman dan sikap para guru pondok pesantren di Kabupaten Tangerang terhadap perbankan syariah tinggi dan ada pengaruh antara pemahaman produk bank syariah guru pondok pesantren terhadap sikap menggunakan produk bank syariah.
\end{abstract}

Kata kunci: pemahaman, sikap, guru, produk bank syariah

\section{Pendahuluan}

Perbankan syariah adalah suatu yang baru di Indonesia. Sebagian besar masyarakat Indonesia hanya mengetahui keberadaanya, dan sedikit yang mengetahui perbedaan antara perbankan syariah dengan perbankan konvensional. Keberadaan pondok pesantren di Kabupaten Tangerang berpengaruh terhadap pola pikir masyarakat. Masyarakat cenderung lebih agamis dan menjalankan ajaran - ajaran Islam serta menjauhi larangan- Nya secara utuh. Keberlangsungan lembaga pendidikan seperti pondok pesantren tergantung pada pengurus-pengurus yang mengerti keagamaan, seperti Alim Ulama, Kyai, Ustad dan Ustadzah. Seyogyanya, mereka mengerti konsep kenapa Maysir, Gharar dan Riba dilarang. Pemahaman yang mereka miliki dapat menalari pada anak didiknya, yang kemudian dapat menjadi harapan berkembangnya bank syariah. Alim 
Ulama, Kyai, Ustad Dan Ustdzah adalah pengajar di pondok pesantren yang menjadi panutan bagi siswa atau santri pondok pesantren. Perilaku pengajar cenderung selalu dicontoh oleh santrinya baik dalam hal baik maupun buruk. Tingkat pemahaman guru terhadap suatu konsep berpengaruh terhadap pemahaman siswanya terhadap konsep yang sama. Seorang guru mengajarkan hal baru kepada siswa, maka hal baru akan didapat oleh siswa. Begitu pula dengan keberadaan perbankan syariah di kalangan pendidikan. Jika guru mengetahui perbankan syariah dan memaparkannya kepada siswa dengan baik. Maka bertambah pula para siswa yang mengetahui perbankan syariah.

\section{Pemahaman}

Pemahaman adalah tingkat kemampuan yang mengharapkan seseorang mampu memahami konsep, situasi dan fakta yang diketahuinya. Pemahaman mencakup kemampuan untuk menangkap makna dan arti dari bahan yang dipelajari. Individu dikatakan memahami sesuatu apabila dia mampu memberikan penjelasan atau memberi uraian yang lebih terperinci tentang hal yang dipelajari dengan menggunakan bahasanya sendiri.

Pemahaman merupakan patokan kompetensi yang dicapai setelah individu melakukan kegiatan belajar (Rakhmat,209:66). Dalam proses pembelajaran, setiap individu memiliki kemampuan yang berbeda-beda dalam memahami apa yang dipelajari.

\section{Sikap}

Sikap adalah kecendrungan bertindak, berpersepsi, berpikir, dan merasa dalam menghadapi objek, ide, situasi atay nilai.(Rakhmat,2009:39) Sikap bukan perilaku, tetai merupakan kecendrungan untuk berperilaku dengan cara-cara tertentu terhadap objek sikap. Objek sikap boleh berupa benda, orang, tempat, gagasan atau situasi, atau kelompok. Jadi, pada kenyataannya tidak ada sikap yang berdiri sendiri. Sikap haruslah diikuti oleh kata "terhadap" atau "pada" objek sikap. Sikp cenderung memiliki daya pendorong atau motivasi. Sikap bukan sekedar kenangan masa lalu, tetapi menentukan apakah individu harus setuju atau tidak setuju terhadap sesuatu. Menetukan apa yang disukai, diharapkan, dan diinginkan, menyampingkan apa yang tidak diinginkan, dan apa yang harus dihindari.

Menurut Azwar(2005), komponen- komponen sikap adalah pertama: sikap terbentuk dari pengetahuan dan informasi yang diterima yang selanjutnya diproses menghasilkan suatu keputusan untuk bertindak yang disebut kognitif. Kedua: afektif merupakan masalah 
emosional subjektif sosial terhadap suatu objek, seperti perasaan yang dimiliki individu terhadap suatu objek. Ketiga: Konatif, merupakan bagaimana perilaku atau kecendrungan berperilaku yang ada dalam diri seseorang berkaitan dengan objek sikap yang dihadapinya.

\section{Guru}

Undang -Undang Nomor 14 Tahun 2005 Tentang Guru dan Dosen menjelaskan bahwa Guru adalah pendidik profesional dengan tugas utama mendidik, mengajar, membimbing, mengarahkan, melatih, menilai, dan mengevaluasi peserta didik pada pendidikan usia dini melalui jalur formal pendidikan dasar dan pendidikan menengah. Tugas guru umumnya adalah mewariskan pengetahuan dan berbagai keterampilan kepada generasi muda. Hal-hal yang akan diwariskan itu sudah tentu harus sesuai dengan ukuran- ukuran yang telah ditentukan oleh masyarakat dan merupakan gambaran tentang keadaan sosial, ekonomi, dan politik masyarakat bersangkutan (Hamalik, 2002:44).

Peran guru dalam proses kemajuan pendidikan sangatlah penting. Guru merupakan salah satu faktor utama bagi terciptanya generasi penerus bangsa yang berkualitas, tidak hanya dari sisi intelektualitas saja melainkan dari tata cara berperilaku dalam masyarakat (Suryabrata,1989:255).

\section{Produk Bank Syariah}

Pada dasarnya produk yang ditawarkan bank syariah dapat dibagi menjadi tiga bagian besar, yaitu: (Adiwarna Karim,2004:87)

1. Produk penyaluran dana (financing)

Pembiayaan atau financing ialah pendanaan yang diberikan oleh suatu pihak kepada pihak lain (nasabah) untuk mendukung investasi yang telah direncanakan, baik dilakukan sendiri maupun lembaga. Kata lain pembiayaan adalah pendanaan yang dikeluarkan untuk mendukung investasi yang telah direncanakan. Dalam menyalurkan dananya pada nasabah, secara garis besar produk pengeluaran dana dapat dibagi menjadi empat macam, yaitu: pembiayaan dengan prinsip jual beli, pembiayaan dengan prinsip sewa, pembiayaan dengan prinsip jual beli, dan pembiayaan dengan akad pelengkap.

2. Produk jasa (service)

Selain menjalankan fungsinya sebagai penghubung antara pihak yang membutuhkan dana dengan pihak yang kelebihan dana, bank syari'ah dapat pula melakukan berbagai pelayanan jasa perbankan kepada nasabah dengan mendapat imbalan berupa sewa atau 
keuntungan. Jasa perbankan tersebut antara lain berupa sharf (jual beli Valas), Ijarah (sewa),

3. Produk penghimpun dana (funding)

Produk penghimpunan dana pada bank syariah disesuaikan pada tiga fungsi, yaitu tabungan, giro, dan deposito. Prinsip operasional syariah yang diterapkan dalam penghimpunan dana masyarakat adalah wadiah dan mudharabah.

\section{Metode}

Metode yang digunakan metode kualitatif, dengan tujuan menyelidiki, menemukan, menggambarkan, dan menjelaskan kualitas atau keistimewaan dari pengaruh sosial yang tidak dapat di ukur, secara kuantiatif.

Responden dalam penelitian ini adalah Guru pondok pesantren yang berjumlah 97 orang dari Pondok Pesantren Al-Ma'mur, Pondok Pesantren Islahul Ummah, dan Pondok Pesantren Daar el-Qolam.

Alat ukur untuk mengumpukan data adalah dengan Kuesioner/Angket Untuk mempermudah responden di berikan daftar pertanyaan dengan disediakan pilihan. Format jawabanya yang digunakan adalah skala likert. Skala Likert adalah skala yang digunakan untuk mengukur persepsi sikap atau pendapat seseorang atau kelompok mengenai sebuah peristiwa atau penomena sosial, berdasarkan definisi operasional yang telah ditetapkan oleh peneliti.

Skala likert mengungkapkan sikap dari responden dalam bentuk jawaban skor: Sangat Setuju $(S S)=5$, Setuju $(S)=4$, Ragu-ragu $(R R)=3$, Tidak Setuju (TS) $=2$, dan Sangat Tidak Setuju (STS) $=1$, Angket disebar kepada guru Pondok tersebut. Kemudian akan di tabulasi dan di olah di program untuk mengetahui hasil proporsi atau presentasi, dan banyaknya atau frekuensi dari skor tersebut. Untuk mempermudah melakukan penelitian maka penelitian menggunakan alat analisis yaitu program SPSS 21. Alat-alat yang digunakan untuk melakukan analisis data kualitatif pada penelitian ini antara lain, yaitu: (1) Uji validitas digunakan untuk mengukur valid tidaknya kuesioner.(2) Uji Reliabilitas adalah untuk mengukur kuesioner yang merupakan indikator dari variabel.(3) statisitik yang digunakan untuk menganalisis data dengan cara mendeskripsikan atau menggambarkan data yang telah terkumpul(4) Uji Asumsi Klasik (5) Uji hipotesis merupakan jawaban sementara terhadap rumusan masalah penelitian. 


\section{Hasil dan Pembahasan}

Hasil penelitian menunjukan bahwa pemahaman dan sikap para guru pondok pesantren di Kabupaten Tangerang terhadap perbankan syariah sangat tinggi, hal ini dapat terlihat dari hasil penyebaran angket kepada 97 responden. Berdasarkan data yang diperoleh melalui uji regresi, menunjukan bahwa variabel pemahaman memberikan sumbangsih terhadap variabel sikap sebesar 40.8\%. Sehingga ada pengaruh antara pemahaman produk bank syariah guru pondok pesantren terhadap sikap menggunakan produk bank syariah.

\section{Tabel 1}

\section{Validitas Pemahaman produk bank syariah guru pondok pesantren}

\section{Correlations}

\begin{tabular}{|c|c|c|c|c|c|c|}
\hline Q5 & Q6 & Q7 & Q & Q9 & Q10 & Total \\
\hline 103 & .159 & .151 & .164 & 147 & -.115 & $415^{* *}$ \\
\hline |.314 & |.119 & |.140 & |.109 & |.152 & $\mid .263$ & 1.000 \\
\hline
\end{tabular}




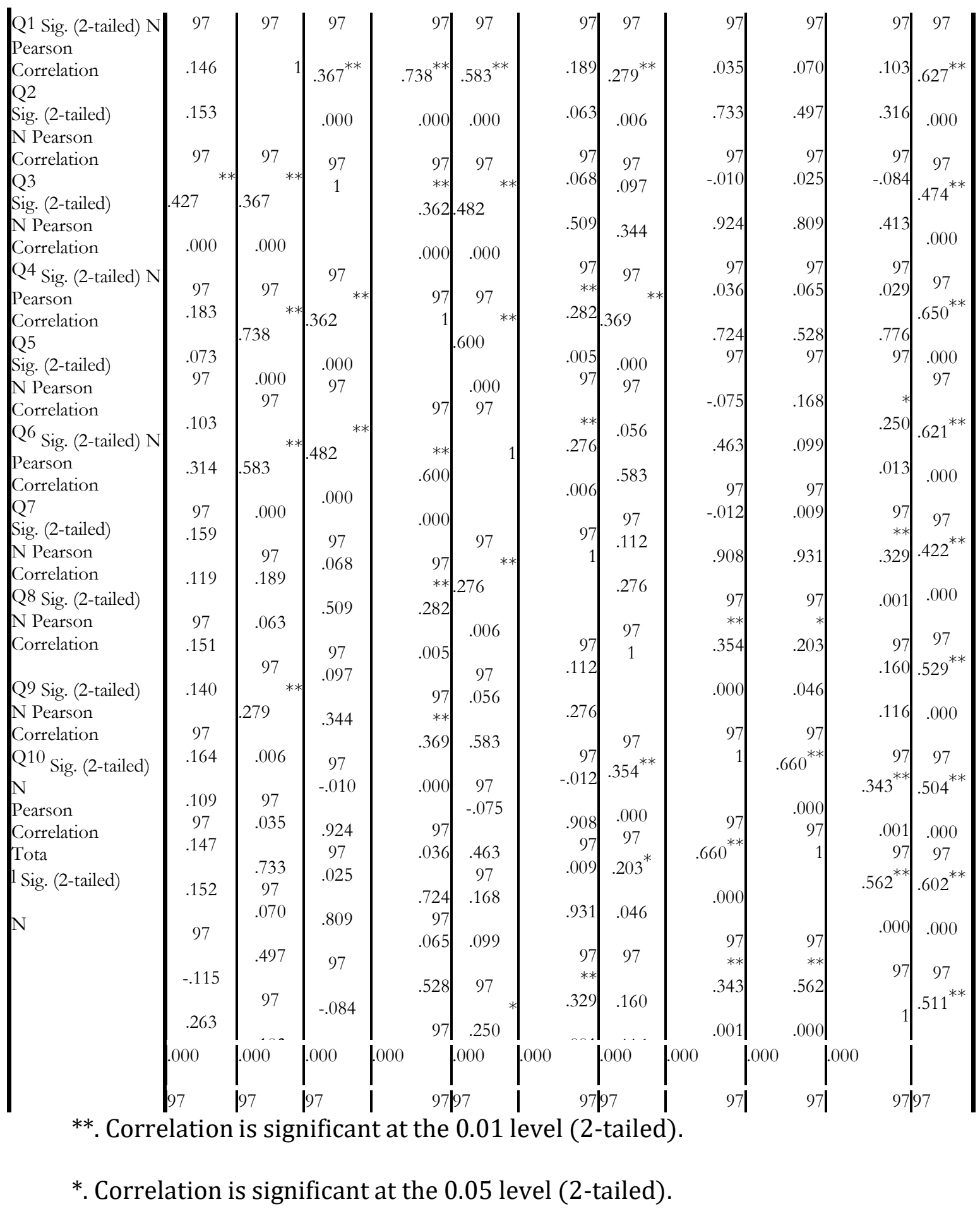


Tabel 2

Sikap Menggunakan Produk Bank Syariah

Correlations

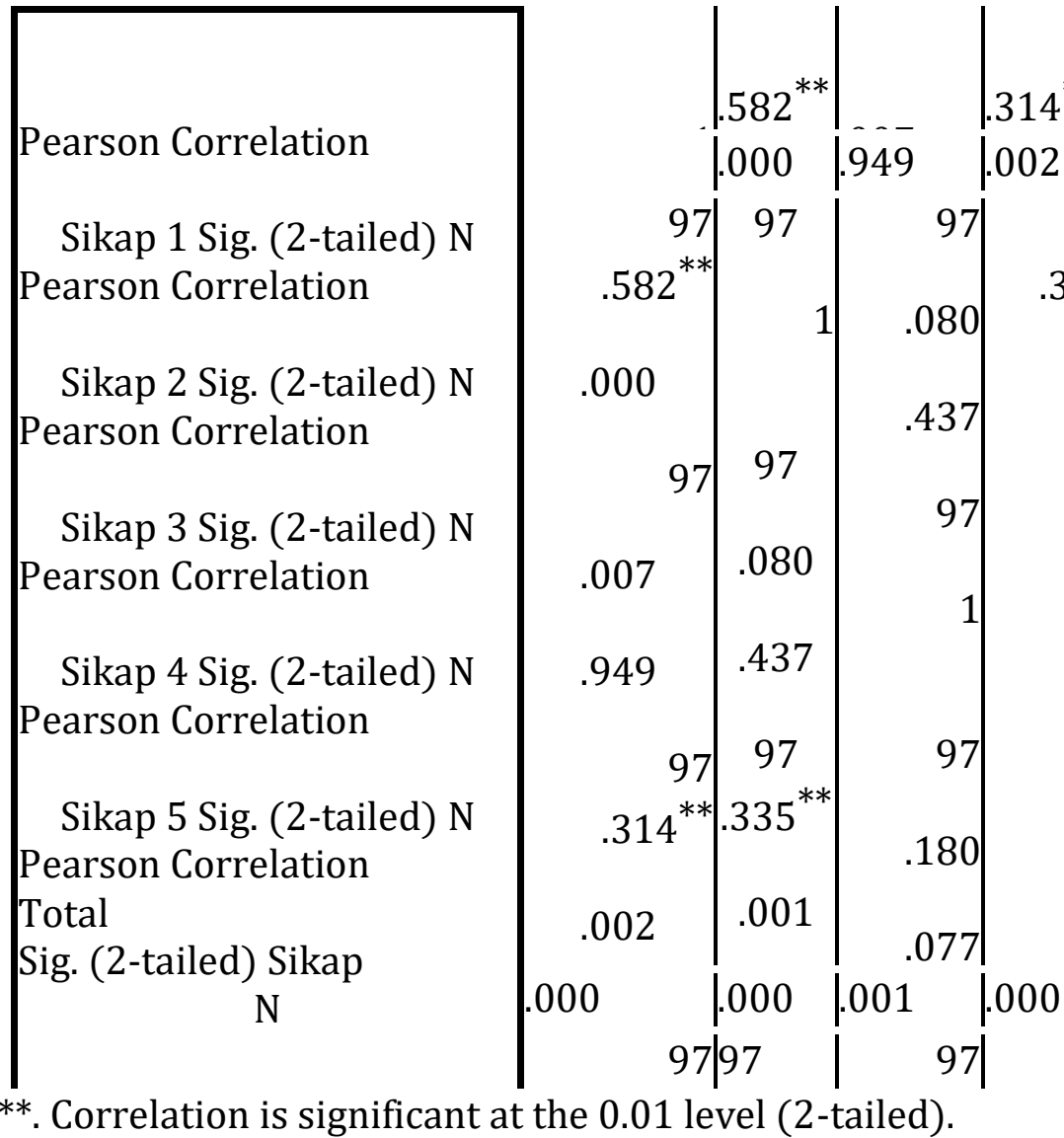

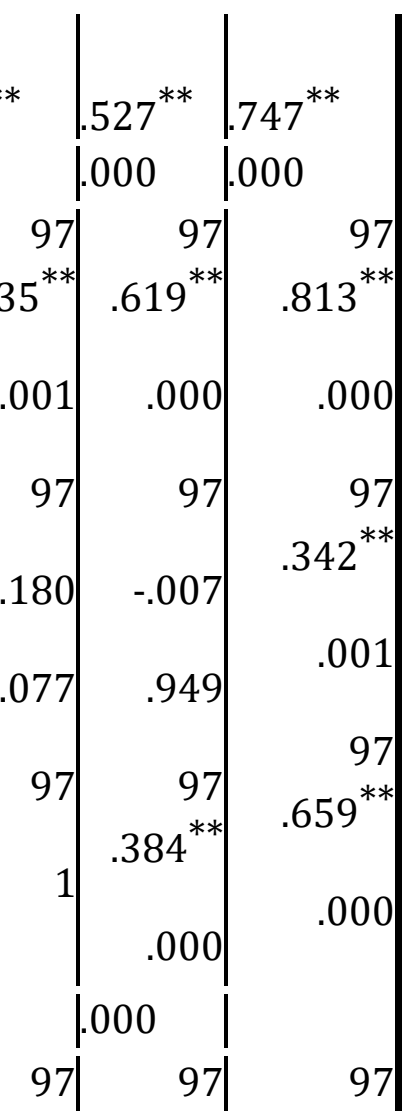

Berdasarkan hasil olah data di atas, maka dapat disimpulkan bahwa semua item dinyatakan valid karena nilanya lebih besar dari pada rtabel yaitu 0.198

Tabel 3

Pemahaman Produk Bank Syariah Guru Pondok Pesantren Reliability Statistics

\begin{tabular}{r|r|r}
$\begin{array}{l}\text { Cronbach's } \\
\text { Alpha }\end{array}$ & $\begin{array}{c}\text { Cronbach's Alpha Based on } \\
\text { Standardized Items }\end{array}$ & N of Items \\
.721 & .727
\end{tabular} \mid

Uji reliabilitas yang dilaksanakan dengan sampel uji instrumen sebanyak 97 respondendan 10 item pertanyaan. Uji reliabilitas ini menggunakan uji statistik Cronbach's Alpha pada program SPSS 21 dapat 
diketahui besarnya koefisien reliabilitas skala adalah 0.721 yang berarti sangat reliabel, karena semakin tinggi koefisien reliabilitas mendekati angka 1.00 maka semakin tinggi reliabilitas, dan artinya skor hasil tes semakin terpercaya.

Tabel 4

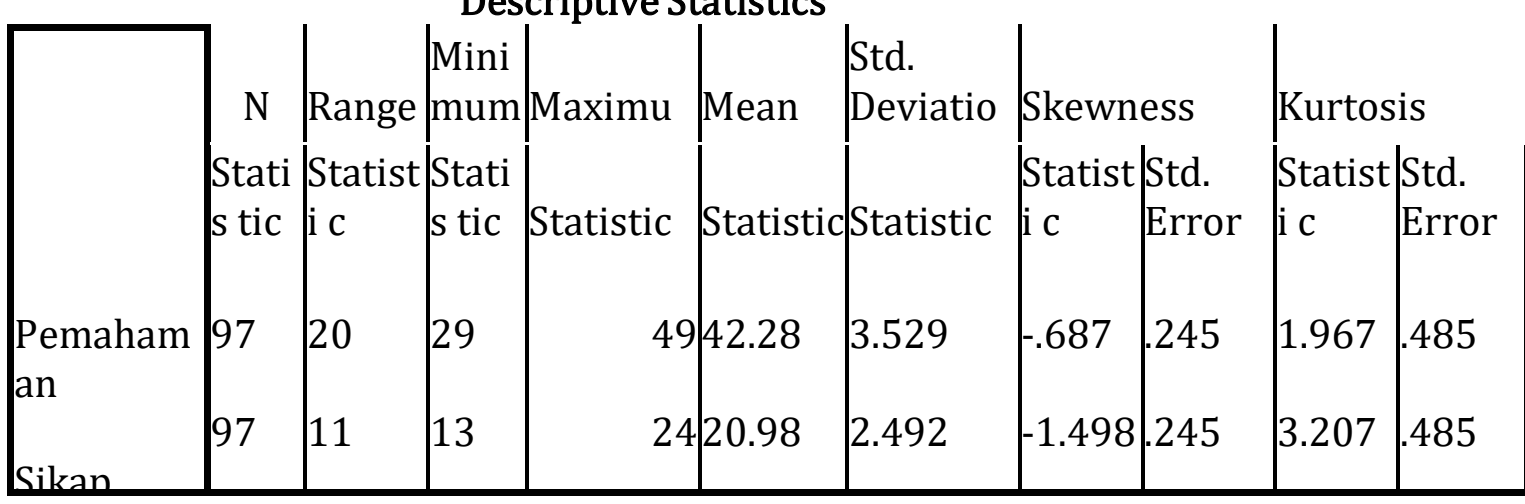

Berdasarkan pada tabel 4.9 dapat dilihat bahwa: 1) Nilai dari Pemahaman produk bank syariah guru memiliki nilai minimum 29, nilai maksimum 49 dan rata- rata 42.28. 2) Nilai dari Sikap menggunakan poduk bank syariah adalah nilai minimum 13, maksimum 24 dan ratarata 20.98 .

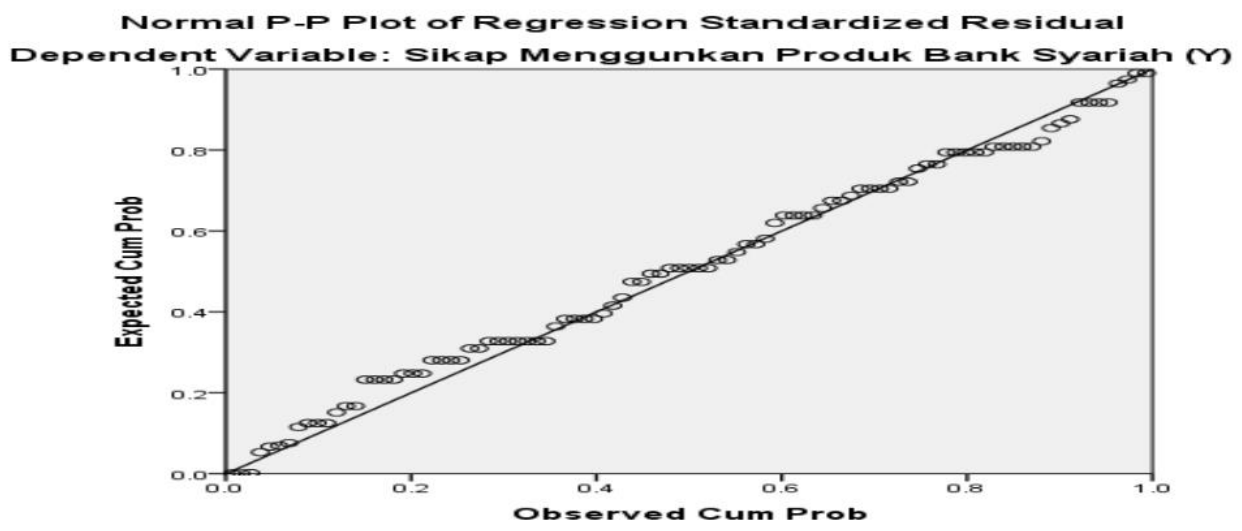

Berdasarkan gambar di atas penyebaran data secara umum terlihat titik-titik berada pada garis diagonal mengikuti arah garis diagonal. Data dikatakan berdistribusi normal, jika data menyebar disekitar garis diagonal dan mengikuti arah garis diagonal, dan sebaliknya. Maka bisa ditarik kesimpulan bahwa dapat dikatakan distribusi normal. 
Tabel 5 hasil uji t (persial)

\section{Coefficients $^{\mathrm{a}}$}

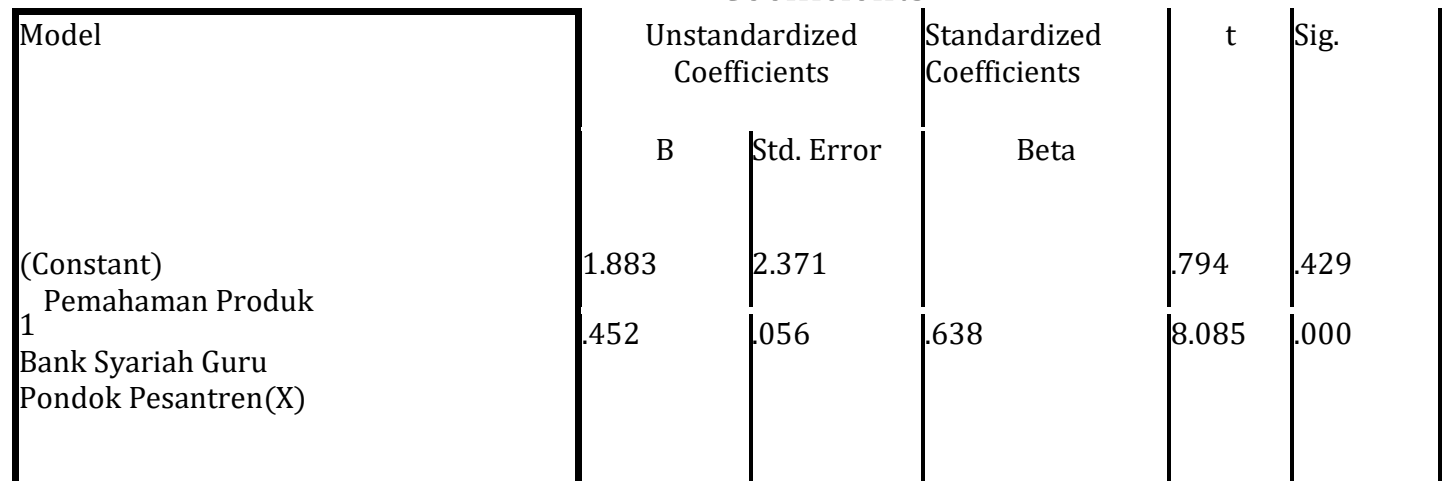

a. Dependent Variable: Sikap Menggunkan Produk Bank Syariah (Y)

Terlihat pada tabel di atas model 1 terdapat nilai signifikan 0.00 . nilai signifikan lebih kecil dari pada 0.05. maka H1 diterima dan H0 ditolak. Variabel pemahaman Produk bank syariah guru pondok pesantren mempunya titung 8.085 dengan ttabel $=0.198$ jadi thitung $>$ ttabel dapat disimpulkan bahwa variable pemahaman produk bank syariah guru pondok pesantren memiliki kontribusi terhadap Y. Nilai $t$ positif menunjukan bahwa variabel $X$ mempunyai hubungan yang searah dengan Y. Jadi, pemahaman produk bank syariah guru pondok pesantren memiliki pengaruh signifikan terhadap sikap menggunakan produk bank syariah.

Tabel 6 Uji Statsitik F

$\mid$\begin{tabular}{l|} 
Model \\
Regression
\end{tabular}

ANOVA $^{\mathrm{a}}$

a. Dependent Variable: Sikap Menggunkan Produk Bank Syariah (Y)

b. Predictors: (Constant), Pemahaman produk Bank Syariah Guru pondok Pesantren $(\mathrm{X})$ 


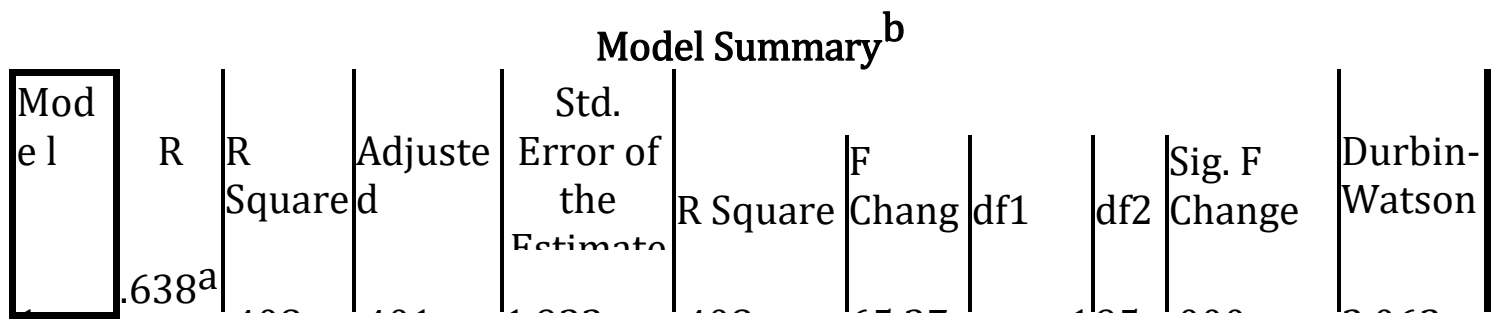

a. Predictors: (Constant), Pemahaman produk Bank Syariah Guru pondok Pesantren $(\mathrm{X})$

b. Dependent Variable: Sikap Menggunkan Produk Bank Syariah (Y)

Dari uji F, diperoleh F hitung sebesar 65.374 dan signifikan 0.000. Maka dapat dinyatakan bahwa model regresi cocok dengan data yang ada, atau dapat diartikan variabel pemahaman produk bank syariah guru pondok pesantren tersebut secara signifikan dapat memprediksi variabel sikap menggunakan produk bank syariah guru pondok pesantren di Kabupaten Tangerang. Artinya variabel Pemahaman berpengaruh terhadap variabel sikap para guru pondok pesantren terhadap penggunaan produk bank syariah.

Berdasarkan data yang diperoleh melalui tabel di atas terlihat nilai R Square menunjukan nilai sebesar 0.408 . Hal ini berarti bahwa variabel Pemahaman memberikan sumbangsih terhadap variabel Sikap sebesar 40,8\%. dengan demikian,perubahan sikap sebesar 59,2\% sisanya dapat dijelaskan oleh variabel selain variabel pemahaman.

\section{Tabel 7 hasil uji Koefisien Determinasi}

\begin{tabular}{|l|c|l|l|l|l|} 
Model & R & R Square & $\begin{array}{l}\text { Adjusted } \\
\text { R Square }\end{array}$ & $\begin{array}{c}\text { Std. Error of the } \\
\text { Estimate }\end{array}$ & $\begin{array}{l}\text { Durbin-Watson } \\
\text { R Square Change }\end{array}$ \\
1 & $.4038^{\mathrm{a}}$ & .408 & .401 & 1.933 & .408
\end{tabular}

a. Predictors: (Constant), Pemahaman produk Bank Syariah Guru pondok Pesantren $(\mathrm{X})$

b. Dependent Variable: Sikap Menggunkan Produk Bank Syariah (Y)

Nilai R Square sebesar 0.408 memiliki arti bahwa kemampuan variabel bebas untuk menjelaskan besarnya variasi dalam variabel terikat adalah sebesar $40.8 \%$ sisanya dijelaskan variabel lain yang tidak termasuk dalam analisis ini. 


\section{Kesimpulan}

Dari analisis data dalam penelitian ini maka dapat disimpulkan bahwa tingkat pemahaman produk bank syariah guru pondok pesantren di Kabupaten Tangerang dapat dibilang positif atau sangat tinggi. Hal ini dapat dilihat dari hasil penyebaran kuesioner/ angket yang telah diberikan kepada 97 responden guru di 3 pondok pesanren. Berdasarkan data yang diperoleh melalui uji regresi, menunjukan bahwa variabel pemahaman memberikan sumbangsih terhadap variabel sikap sebesar 40.8\%. Sehingga ada pengaruh antara pemahaman produk bank syariah guru pondok pesantren terhadap sikap menggunakan produk bank syariah.

\section{Daftar Pustaka}

Al-Quran dan Terjemah

Antonio,Muhammad Syafii, Bank Syariah Dan Teori Ke Praktek,(Jakarta: gema insani, 2001)

Apud, Diktat Pengantar Metodoligi Penelitian, (Banten, IAIN SMHB, 2011) Bungin, Burhan. Penelitian Kualitatif: Komunikasi, Ekonomi, Kebijakan Publik dan Ilmu Sosiallainnya. (Jakarta: Kencana,2008)

Depertemen Pendidikan dan Kebudayaan, Kamus Besar Bahasa Indonesia, (Jakarta,1986)

Desmawarita dan Linda Aryani Kepercayaan Mahasiswa Terhadap Ustad: Pendekatan Indigenous Psikologi (Jurnal, UIN Sultan Syarif Kasim Riau,2014)

Dewan Syariah Nasional, Himpunan Fatwa Dewan Syariah Nasinal (Jakarta:2003)

Dr. Said Saad Marthon, Ekonomi Islam Di Tengah Krisis Ekonomi Global (Jakarta,2004)

Faad Noer, dan Yulizar Djamaludin Sanergo,Preferensi Masyarakat Pesantren Terhadap Bank Syariah(Studi Kasus DKI Jakarta, (Jurnal,Tazkia)

Hamalik, Oemar, Perencanaan Pengajaran berdasarkan Pendekatan Sistem,(Jakarta,2002)

Haroen, Nasrudin. Fiqh Muamalah, (Jakarta,Gaya Medina Pratama.2000)

Kasmir, Manajemen Perbankan, ( Jakarta, Raja Grafindo, 2001)

Mastuhu, Dinamika Sistem Pendidikan Pesantren, ( Jakarta,INIS, 1994)

Mundzier, Amin. Dkk. Manajemen Pondok Pesantren (Jakarta: Diva Pustaka,2003),

Rakhmat, Jalaluddin. Psikologi Komunikasi. ( Bandung, Rremaja Rosdakarya:2009) 
Rizkiyanto, Ilham Afika. Persefi Guru Pesantren At-Taqwa Bekasi Terhadap Bank Syariah, Skripsi.Universitas Islam Negeri Jakarta (2014)

Ruseffendi, E.T., Pengantar Kepada Membantu Guru Mengembangkan Kopetensinya Dalam Pengajaran Matemaika Untuk Meningkatan CBSA (Bandung, Tartiso,2009)

Salim, Peter. Kamus Populer Bahasa Indonesia, ( Jakarta, Balai Pustaka,1998)

Sugiyono, Metode Penelitian Pendidikan (Bandung, Alfabeta,2015)

Suhendi, Hendi. Fiqih Muamalah, (Jakarta, Raja Grafindo Persada,2011)

Suryabrata, Sumadi. Psikologi Pendidikan, (Jakarta,Rajawali,1989)

Veitzal Rivai, dkk. Ekonomi Syariah: Konsep, Praktek \& Penguatan Kelembagaannya. (Semarang, Pustaka Rizki Putra, 2009)

Wangsawidjaja. Pembiayaan Bank Syariah. (Jakarta:Gramedia Pustaka Utama 2012)

www. Daarelqolam.ac.id

Zamakhasyari Dhofier, Tradisi Pesantren: Studi tentang pandangan hidup kyai (Jakarta, LP3s,1985) 